\title{
Comments on snails of the genus Zoniferella from Ecuador (Mollusca: Achatinidae), with restriction of the type locality "Los Puentes" for several species of Gastropoda and Arachnida
}

\author{
DIEGO F. CISNEROS-HEREDIA ${ }^{1,2} *$ \& ROBERTO F. VALENCIA ${ }^{1,3}$ \\ ${ }^{1}$ Universidad San Francisco de Quito USFQ, Colegio de Ciencias Biológicas y Ambientales, \\ Instituto de Biodiversidad Tropical IBIOTROP, Museo de Zoología, Laboratorio de Zoología \\ Terrestre, Quito 170901, Ecuador \\ ${ }^{2}$ Instituto Nacional de Biodiversidad INABIO, Quito, Ecuador \\ ${ }^{3}$ Université Libre de Bruxelles ULB, Faculté de sciences Biologiques, Bruxelles 1050, \\ Belgique \\ *Corresponding author: diego.cisnerosheredia@gmail.com
}

\begin{abstract}
:
The genus Zoniferella includes six taxa of land snails from Colombia and Ecuador for which little has been published beyond their original descriptions. In this paper, we present new records of Zoniferella vespera, a species previously known only from its type locality, expanding its range across northwestern Ecuador. We provide the first description of the colouration in life for Zoniferella snails. We comment on the similarities among some species of Zoniferella, suggesting the possibility that $Z$. vespera and $Z$. riveti are junior synonyms of $Z$. albobalteata, and $Z$. bicingulata is a synonym of $Z$. riveti var. bizonalis (as $Z$. bizonalis). Finally, we offer evidence to allow the restriction of the locality of "Los Puentes", type locality of Mesembrinis vesperus Jousseaume, 1887 = Zoniferella vespera (Gastropoda: Achatinidae); Isomeria bourcieri lutea Cousin, 1887 (Gastropoda: Labyrinthidae); Guestieria locardi Jousseaume, 1887 (Gastropoda: Scolodontidae); Proserpinella cousini Jousseaume, 1887 (Gastropoda: Proserpinellidae); Idiophthalma robusta Simon, 1889 (Arachnida: Barychelidae); Eurypelma (Lasiodora) augusti Simon, 1889 = Pamphobeteus augusti (Arachnida: Theraphosidae), Eurypelma (Lasiodora) vespertinus Simon, $1889=$ Pamphobeteus vespertinus (Arachnida: Theraphosidae).
\end{abstract}

Keywords: Barychelidae, distribution, colouration, Eurypelma, Idiophthalma, Mesembrinis, Pamphobeteus, Synapterpes, taxonomy, Theraphosidae

Zoniferella Pilsbry, 1906 was described as a subgenus of Synapterpes Pilsbry, 1896, and later recognised as a distinct genus (Bank 2017, MolluscaBase 2022). Zoniferella are land snails characterised by a fragile, thin, glossy greenish-black shell, varying from yellowish olive green on the apex to dark greenish black on most of the shell, having white stripes. Size, number of whorls and stripes vary according to the species and soft anatomy remains unknown (Pilsbry 1906). Six taxa of Zoniferella have been described: Zoniferella albobalteata (Dunker, 1882) (type species by original designation), Z. vespera (Jousseaume, 1887), Z. riveti (Germain, 1907) and Z. riveti var. bizonalis (Germain, 1907), Z. bicingulata (Fulton, 1908), and Z. pilsbryi (Fulton, 1908). The latter was assigned to Zoniferella with uncertainty in its original description.

Nothing has been published in academic sources about Zoniferella species, aside from their original descriptions. This paper aims to present the first records for Zoniferella vespera since its original description, expanding its range across northwestern Ecuador, to comment on other species of Zoniferella from Ecuador, and to restrict the type locality of Mesembrinus vesperus Jousseaume, 1887 (= Zoniferella vespera), which is also the type locality of several other species of gastropods and spiders. 


\section{Zoniferella vespera (Jousseaume, 1887)}

Mesembrinus vesperus Jousseaume, 1887: 168, pl. 3, fig. 2

Mesembrinus vesperus-(Cousin 1887): 234; (Astudillo Espinosa 1978): 57.

Bulimulus visendus-(Hidalgo 1893b): 47-49; (Hidalgo 1893c): 247-248

Bulimulus visendus var. vesperus-(Hidalgo 1893a): 131

Synapterpes (Zoniferella) vesperus-(Pilsbry 1906): 234, pl. 37, fig. 91

Synapterpes vesperus_-(Germain 1907): 61; (Germain 1911): C48.

Zoniferella vespera-(MolluscaBase 2022): AphiaID 995660

Two individuals of Zoniferella vespera were found at the Otonga Reserve $\left(0^{\circ} 26\right.$ '24" S, 78 43'19” W; 1815 m), county of Sigchos, province of Cotopaxi, Republic of Ecuador, on top of leaves of Melastomataceae and Araceae, in a very narrow, steep, and rocky ravine covered by old-growth dense forest, near the main station house, on 28 May 2021 by Roberto Valencia (Fig. 1). The snails were photographed alive, and one is deposited at the Museo de Zoología, Universidad San Francisco de Quito, Ecuador (ZSFQ), under patent 010-UBVSOTQ-DZ2E-MAAE-2021, issued by the Ministry of Environment, Water and Ecological Transition of Ecuador (Fig. 2).

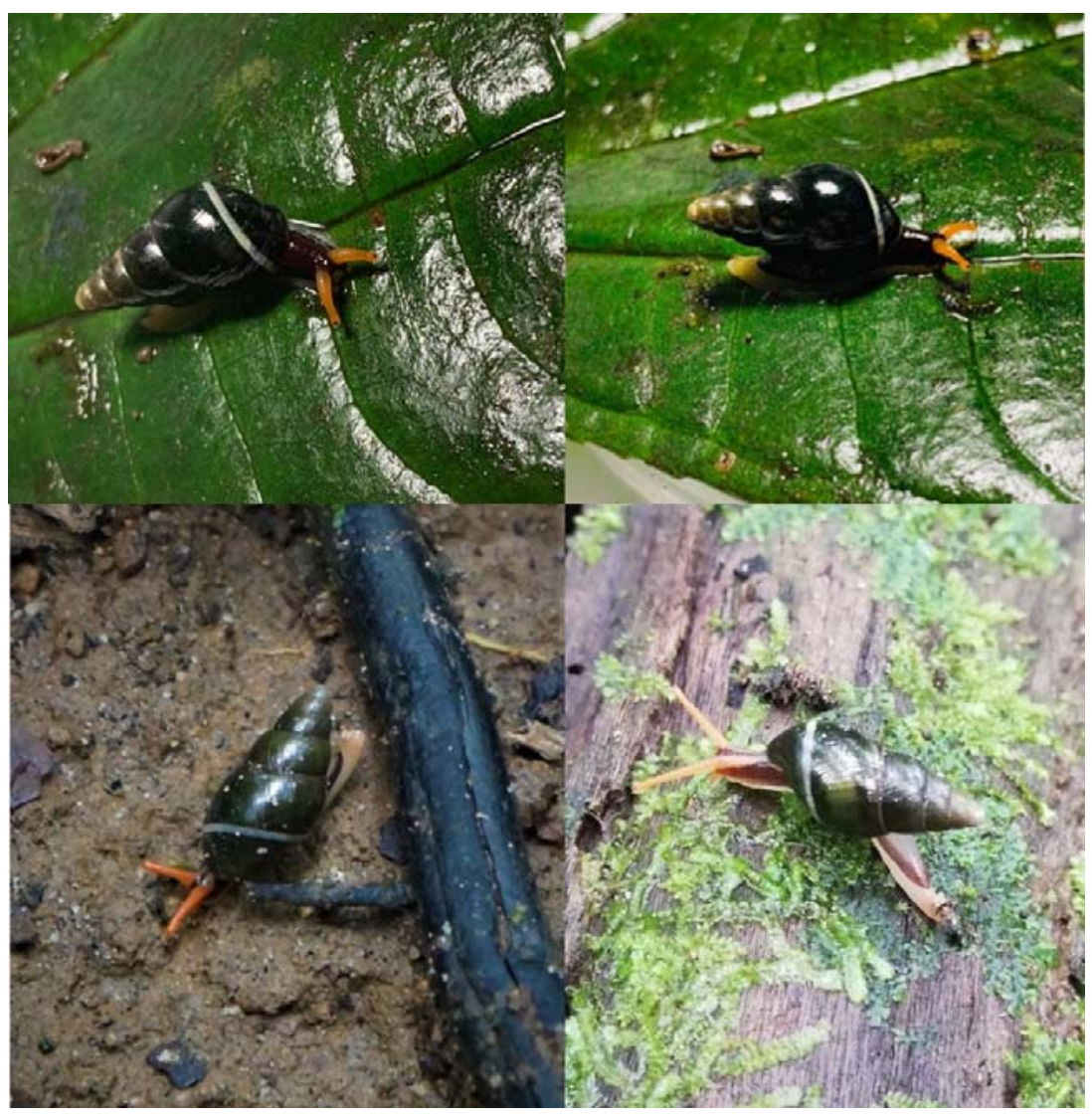

Figure 1. Variation of colouration in life of Zoniferella vespera. Top: Otonga Reserve, province of Cotopaxi, Ecuador, photo by R. Valencia. Bottom left: Un Poco de Chocó Reserva, Pachijal, province of Pichincha, Ecuador, photo by j0rdis, iNaturalist (CC-BY-NC). Bottom right: Estación Mindo USFQ, province of Pichincha, Ecuador, photo by Giovanni Ramón, iNaturalist (CC-BY-NC-SA) 
Photographs of one individual were posted in iNaturalist (Valencia 2021), where initial generic identification was provided. We confirmed the generic and species identification based on information provided by Pilsbry (1906), Jousseaume (1887) and Cousin (1887), and examination of photographs of the holotype (MNHN 2000b). Snails were identified as Zoniferella vespera due to the presence of the following diagnostic characters: shell ovateacuminate, thin, delicate, very glossy, decorated with very thin irregular ridges; 6 whorls; spire long, conic; apex obtuse; aperture oval; peristome simple, acute; columellar margin straight. Shell colouration dark green getting paler towards the apex, with a circular white conspicuous band on the last whorl, and columellar margin whitish (Cousin 1887, Jousseaume 1887, Pilsbry 1906). The new specimen is slightly more globular and smaller than the holotype, but we consider that these differences are due to intraspecific variation (Fig. 2).

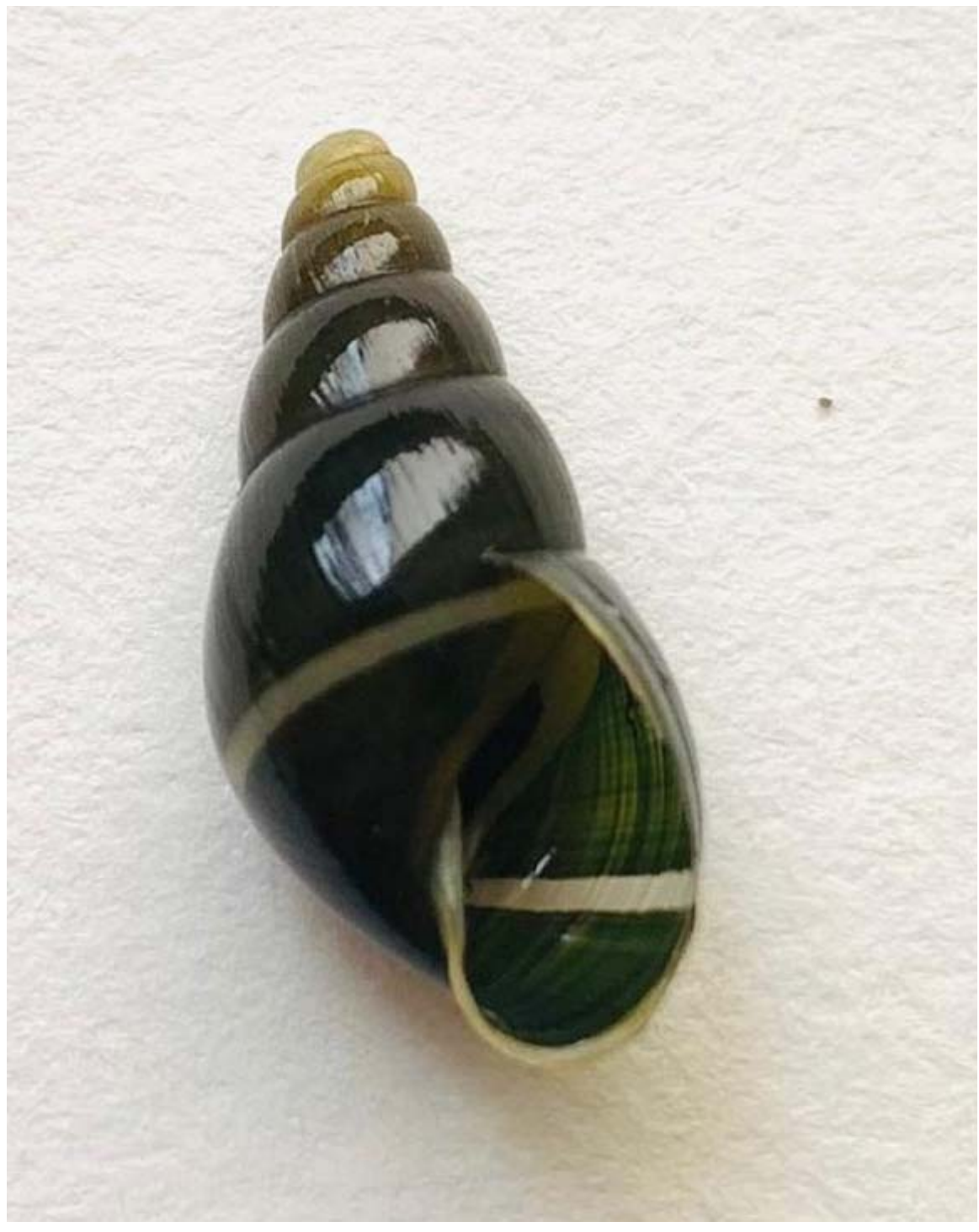

Figure 2. Specimen of Zoniferella vespera from Otonga Reserve, province of Cotopaxi, Ecuador, deposited at the Museo de Zoología, Universidad San Francisco de Quito (ZSFQ). 
Zoniferella vespera is most similar to Z. albobalteata and Z. riveti. Zoniferella albobalteata is currently diagnosed from $Z$. vespera by its smaller length $(13 \mathrm{~mm}$ vs. $17 \mathrm{~mm}$ in the holotype of $Z$. vespera) and subreflexed columella (straight in Z. vespera) (Dunker 1882, Pilsbry 1906). However, size of snails from Otonga is intermediate between both species, but due to the straight columella we assigned them to $Z$. vespera. Zoniferella riveti differ from $Z$. vespera by having 7 whorls, a larger size $(21 \mathrm{~mm})$, more slender shape, and twisted columella (Germain 1907, 1911). Zoniferella riveti var. bizonalis and Z. bicingulata differ from $Z$. vespera by having two white bands on the last whorl, one of which further continues along the other whorls (one band in Z. vespera, restricted to the last whorl) (Germain 1907, 1911, Fulton 1908). Zoniferella pilsbry is easily separated from $Z$. vespera by having the lower whorls with narrow spiral bands green alternating with narrow white bands, eight whorls, and longer length (26 mm) (Pilsbry 1906).

Subtle differences in length (13-21 mm), number of whorls (6-7) and columella shape (straight or twisted) have been used to separate Z. albobateata, Z. vespera and Z. riveti. A similar situation is noted between $Z$. riveti var. bizonalis and Z. bicingulata, and both species were not compared in their original descriptions because they were published a year apart (Germain 1907, Fulton 1908). Based on the data provided in their descriptions and photographs of the holotypes (MNHN 2000a, NHM 2021), they would differ in the number of whorls $\left(6 \frac{1}{2}-71 / 2\right)$ and the shape of the second white band (narrower than the first band in $Z$. $r$. bizonalis, and the same size in Z. bicingulata). However, these differences could be intraspecific variation of single species, suggesting the possibility that $Z$. vespera and $Z$. riveti are junior synonyms of $Z$. albobalteata, as suggested by Hidalgo (1893c), and Z. bicingulata a synonym of $Z$. riveti var. bizonalis (as $Z$. bizonalis). Zoniferella albobalteata is currently known only from its type locality in "humid forests near Pasto, Colombia" (Dunker 1882, Pilsbry 1906), about $180 \mathrm{~km} \mathrm{~N}$ from the known range of $Z$. vespera, while the type locality of $Z$. riveti (San Tadeo hill, road to Pachijal) is about $10 \mathrm{~km} \mathrm{~W}$ from the type locality of $Z$. vespera, and within its distribution range (see below). Unfortunately, the type locality of $Z$. bicingulata was not specified, cited only as Ecuador (Fulton 1908). Decisions about their formal synonymy would require the direct comparison of type specimens and fresh topotypic material.

The colouration in life of $Z$. vespera has not been described. Individual of $Z$. vespera from the Otonga Reserve had the sole and border of foot yellowish cream, dorsal surfaces of foot and head dark purplish, and tentacles bright orange (Fig. 1). This colouration in life is observed in other individuals reported in iNaturalist, with some intraspecific variation observed by some individuals having a whitish or orange band running towards the back from the base to each tentacle, and the tentacles coloured yellowish cream as the border of foot (Fig. 1). The colouration in life of the shell is like the coloration in preservation, but some individuals may look almost black. Photographs reported in iNaturalist of individuals with two bands on the last whorl (Z. riveti var. bizonalis / Z. bicingulata) usually differ by having the tentacles completely dark like the dorsal surfaces of foot and head, except for the eyes that are cream (Fig. 3). However, one individual showing two bands has the same colouration described for Z. vespera (Obando 2020) and another has tentacles completely cream-coloured and a whitish band running towards the back from the base to each tentacle (Stegenga 2022) (Fig. 3). 


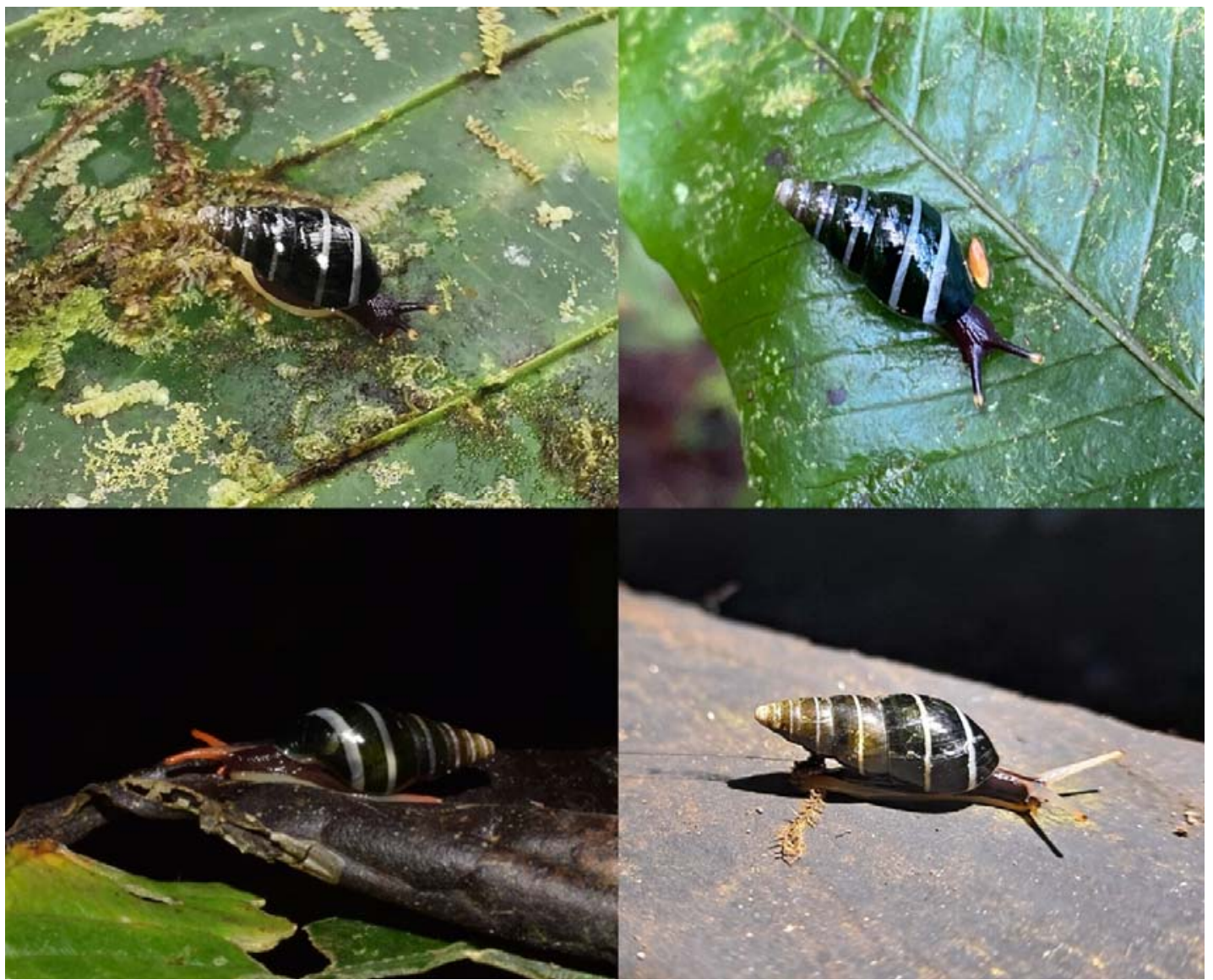

Figure 3. Variation of colouration in life of Zoniferella riveti var. bizonalis / Z. bicingulata. Photos by Barna Takats (top left), Seth Ames (top right), Ben Stegenga (bottom left), Eduardo Obando (bottom right), iNaturalist (CC-BY-NC).

"Los Puentes" is the type locality of several taxa of molluscs and spiders, including Zoniferella vespera (Jousseaume, 1887); Isomeria bourcieri lutea Cousin, 1887; Guestieria locardi Jousseaume, 1887; Proserpinella cousin Jousseaume, 1887; Idiophthalma robusta Simon, 1889; Pamphobeteus augusti (Simon, 1889); and Pamphobeteus vespertinus (Simon 1889) (Cousin 1887, Jousseaume 1887, Simon 1889, Breure 2020). However, the precise position of "Los Puentes" has not been established and some authors became confused by descriptions stating that it was "near Quito", suggesting that Los Puentes was in the interAndean valley of Quito. Jousseaume (1887) provided the following information about the type locality of Mesembrinus vesperus (now Zoniferella vespera): “A single example of this species was collected by our colleague, Mr. A. Cousin, in his property of Los Puentes, near Quito". Simon (1889) cited the type locality of Idiophthalma robusta as "Los Puentes, near Quito"; he reported specimens of Linothele longicauda (Ausserer, 1871) and Cyclosternum schmardae Ausserer, 1871-whose type locality is Quito, from "Los Puentes, near Quito" and "Los Puentes..., around Quito". For C. schmardae, Simon (1889) said "we also received it from Los Puentes and Rumipamba, around Quito, by Mr. A. Cousin”, implying that, like Rumipamba, Los Puentes was in the inter-Andean valley of Quito.

Most collections from Los Puentes were obtained by Auguste Edouard Cousin (Paris, 1835Quito, 1899, see Breure 2020, Correoso Rodríguez 2020). Cousin published a single but important academic publication: "Faune malacologique de la République de l'Équateur" 
(Cousin 1887), where he regularly cited "Los Puentes, near Gualea" when commenting on the distribution of several species (e.g., Cyclophorus esmeraldensis, Mesembrinus visendus, Porphyrobaphe irroratus, Drymaeus petasites, Ammonoceras flora, Psadara selenostoma, Isomeria bourcieri, and Obeliscus cuneus), and said that he found Bourciera helicinaeformis "On the road from Quito to Gualea, towards Hacienda de Los Puentes". Cousin cited "Los Puentes, parish of Calacalí, prov. of Pichincha" in the distribution of Eurytus taylorianus, and "Los Puentes, county of Quito" for Isomeria cymatodes and Cyclotus fischeri. Cousin also provided information about the altitude of Los Puentes, saying that it was "More of less 1500 $\mathrm{m}$ " for M. visendus and "about $1500 \mathrm{~m}$ " for O. cuneus. Pilsbry (1906) cited the locality as "Los Puentes near Gualea at about 1500 meters... (Cousin)" for O. cuneus, based on the information provided by Cousin (1887). Paul Rivet apparently collected at Los Puentes during his expeditions of the Second Geodesic Mission to Ecuador, since Germain (1907, 1911) cited specimens of Bulimus (Porphyrobaphe) irroratus collected by Rivet at "Los Puentes, road of Gualea". Francisco Cousin, son of Auguste Cousin, was friend with Rivet (Jarrín 2021), and probably invited Rivet to the Cousin family's farm at Los Puentes. Breure (2020) reported that the label accompanying the types of Proserpinella cousini said "Los Puentes San Fernandino", however, the photographs of the labels shown that it was written "Los Puentes S. Fernando" and not "Fernandino" (Breure 2020: figs. 31-32). Correoso Rodríguez (2020) mentioned that "Los Puentes" was in northwestern Pichincha and that Auguste Cousin bought the farm in 1866.

Based on the map by Wolf (1892), a bridle path connecting Quito with Gualea started going north across the inter-Andean valley of Quito towards the towns of Cotocollao and Pomasqui, then climbing the western Andean Mountain range through the Casitagua and Pululahua mountain pass towards Calacalí and Nono and running down the western slopes of the Andes towards Nanegal and Gualea (Fig. 4). Los Puentes is mentioned in an executive decree issued by Eloy Alfaro, president of Ecuador, on 14 June 1898 and included in the report presented by Ricardo Valdivieso of the Ministry of Public Works to the Congress of 1899 (Valdivieso 1898). The decree responded to requests submitted by people from the region of Gualea to improve the local bridle path and confirms that the farm Los Puentes was in the parish of Nanegal and on the Quito-Nono-Gualea road:

Translation: Art. $1^{\circ}$ Repair the bridle path from Gualea to Nono. Art. $2^{\circ}$ For this work the owners of rustic estates of the parish of Gualea will contribute, once only, with $7 \%$ of the value of their properties. The farms "Chiquilpe" of the parish of Nono and "Los Puentes" of Nanegal, will contribute with the same contribution. 


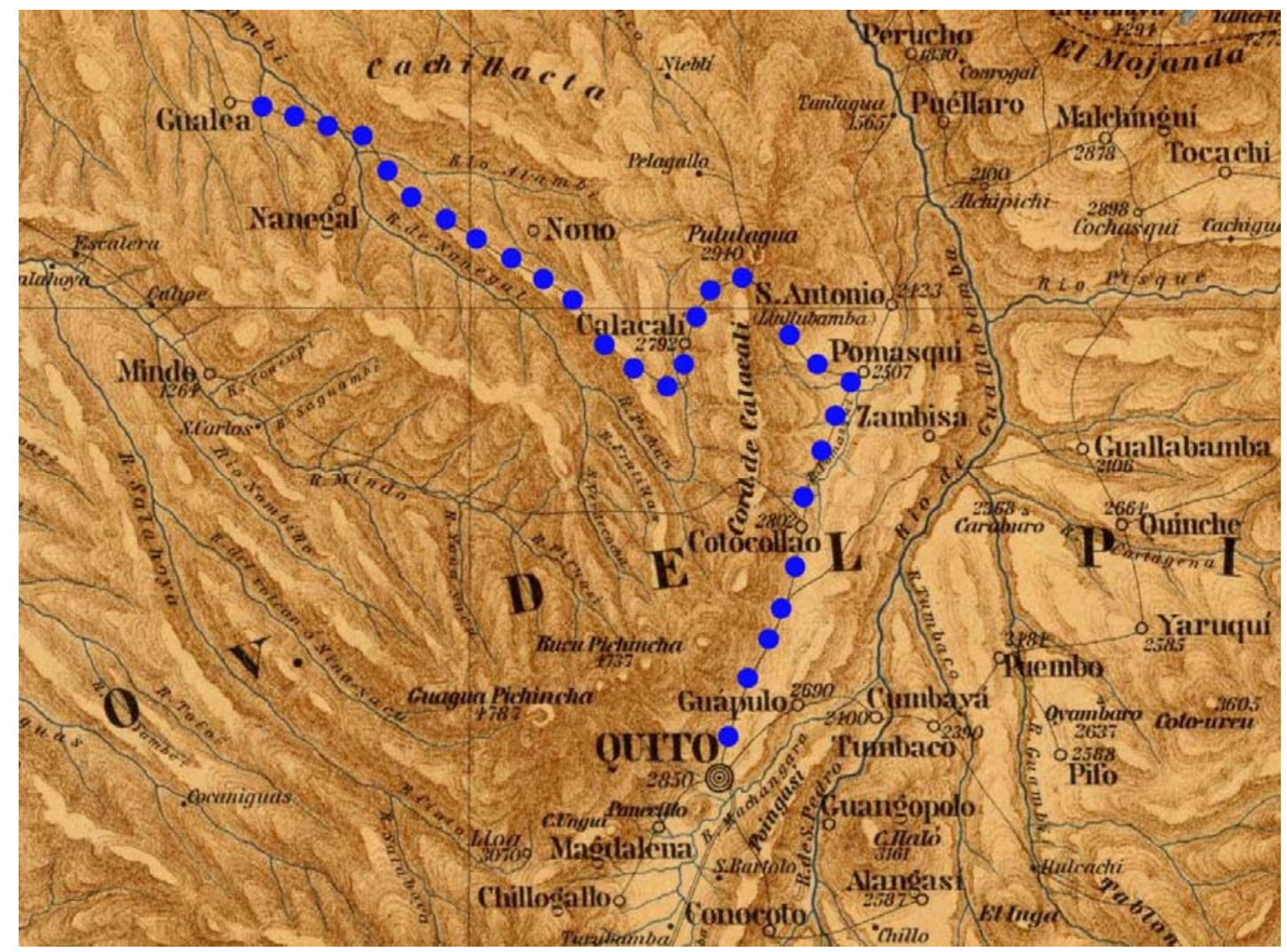

Figure 4. Section of the Carta Geográfica del Ecuador by Theodore Wolf (1892) indicating the Quito-Gualea bridle path (blue dots). Dark lines indicate roads and bridle paths.

During the second half of the $20^{\text {th }}$ century, sections of the Quito-Nono-Gualea bridle path were the basis for the construction of the Quito-Nono-Nanegalito road and the CalacaliNanegalito-Puerto Quito highway. "Los Puentes" literally means "the bridges" in Spanish, and there were many bridges in the old bridle path from Quito to Gualea in the $19^{\text {th }}$ century. However, there is a single locality called "Los Puentes" in the region of the old bridle path and modern road/highway, nowadays classified as a neighbourhood of the parish of Nanegal (IGM 1990, DIPLA n.d., GAD Pichincha n.d.). This locality lies very close to an area where large bridges have been historically built to cross a river junction. About $2 \mathrm{~km} \mathrm{NE}$ from this locality, there is an area known as "San Fernando Cuatro Hermanos", which would coincide with the locality mentioned for Proserpinella cousini.

The correct definition of a type locality is key to understand the distribution of a species because it corresponds to the original locality where the name-bearing type was collected.

Following recommendation by (ICZN 1999, see discussion by Cisneros-Heredia 2017), we restrict the type localities of Isomeria bourcieri lutea Cousin, 1887 (Gastropoda:

Labyrinthidae); Guestieria locardi Jousseaume, 1887 (Gastropoda: Scolodontidae); Proserpinella cousini Jousseaume, 1887 (Gastropoda: Proserpinellidae); Mesembrinis vesperus Jousseaume, 1887 (Gastropoda: Achatinidae); Idiophthalma robusta Simon, 1889 (Arachnida: Barychelidae); Eurypelma (Lasiodora) augusti Simon, 1889 (Arachnida: Theraphosidae), Eurypelma (Lasiodora) vespertinus Simon, 1889 (Arachnida: Theraphosidae), and any other species whose name-bearing type material was collected at "Los Puentes", the farm of the Cousin family in northwestern Ecuador, as follows: Los Puentes, near Nanegalito, at 1500 m elevation, province of Pichincha, República del Ecuador. 
Coordinates focus point: $0.045833,-78.674167$, radius: $2 \mathrm{~km}$. The newly restricted type locality is described as a circle, with a focus point and a radius to describe the associated uncertainty as a maximum distance from that point within which the locality is expected to be found (i.e., point-radius method, Wieczorek et al. 2004). A KMZ file showing this locality is available here: https://doi.org/10.6084/m9.figshare.19297532. In addition to Los Puentes and Otonga Reserve, observations of $Z$. vespera have been reported on iNaturalist from several localities in northwestern Ecuador: valley of Mindo and surrounding mountains, Pachijal, Mashpi, province of Pichincha; and, San Francisco de las Pampas, province of Cotopaxi (Fig. 5 , see Supplementary file 1).

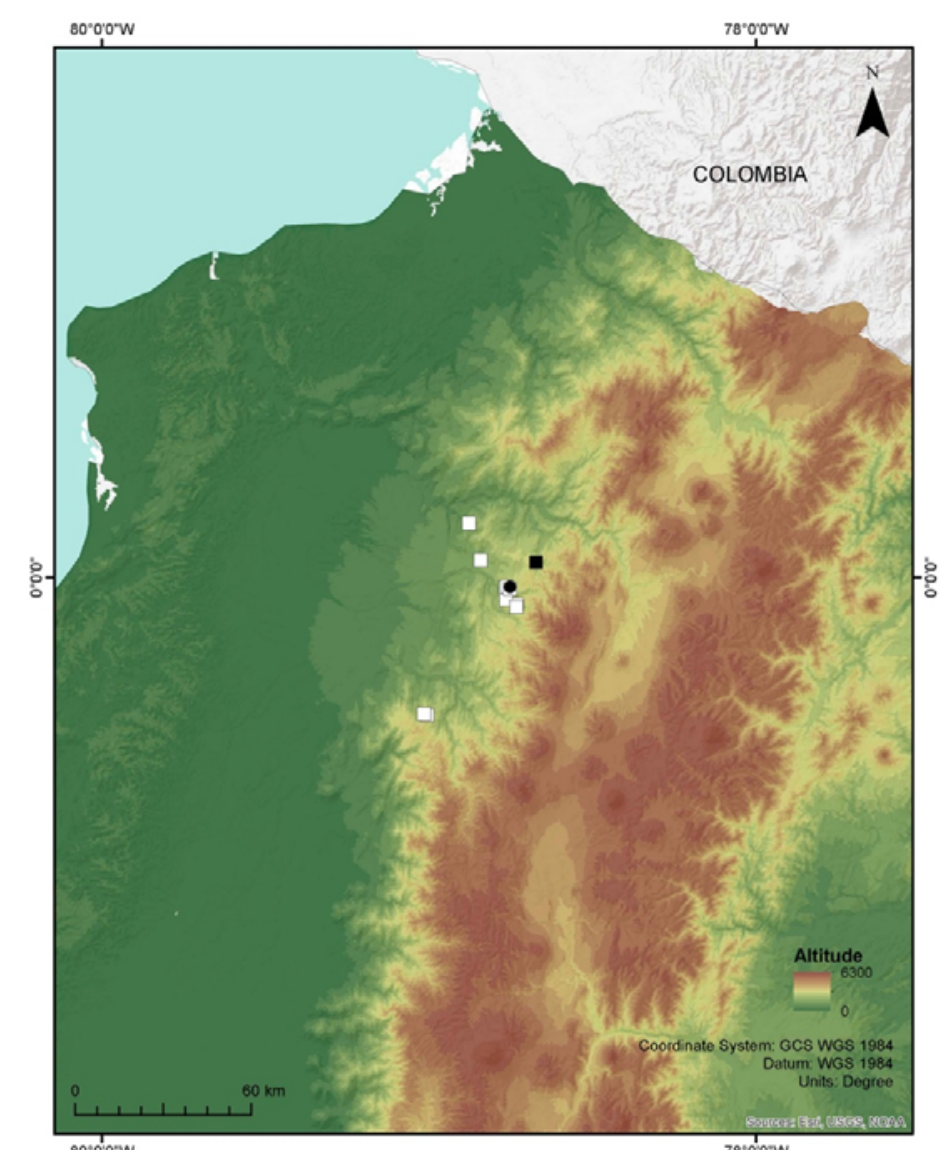

Figure 5. Map of northwestern Ecuador showing the type locality (black square) and other known localities (white squares) of Zoniferella vespera, and the type locality of $Z$. riveti and Z. riveti var. bizonalis (black circle).

Extensive habitat changes and loss across Ecuador have most probably threatened and pushed towards extinction several snail species. The montane cloud forests on the northwestern Andean slopes of Ecuador, habitat of Zoniferella vespera, have been deeply affected by deforestation for timber extraction, agricultural expansion, and mining projects, with few oldgrowth forest fragments remaining in the region. Information on the diversity, ecology, and biogeography of terrestrial snails of Ecuador is deficient. Aside from some works by Abraham Breure, Francisco Borrero, Modesto Correoso and collaborators (Breure and Borrero 2008, Correoso Rodríguez 2008, 2010, Borrero and Araujo 2012, Breure and Araujo 2017, Breure 2020), little has been published on the fauna of terrestrial snails from Ecuador in recent years. 


\section{Acknowledgements}

We thank Sergio Norona, guide at Otonga Reserve, and Roberto León and Samuel Cortese for their help in the field; Giovani Ramón and Emilia Peñaherrera of the Museo de Zoología of Universidad San Francisco de Quito USFQ for their support during lab work; Matt Parr for suggesting the generic identification in iNaturalist; and xx reviewers for their comments on the manuscript. We are grateful to the Otonga Reserve for allowing us to venture into the cloud forest that they have protected for decades; to the Natural History Museum London and the Muséum national d'Histoire naturelle for offering online photographs of type specimens; and to the Biodiversity Heritage Library BHL, Google Books, Archive.org and the World Spider Catalog for making important literature freely available. This work was supported by Universidad San Francisco de Quito USFQ through research and outreach funds (HUBI ID $1057,607)$ and operative funds assigned to IBIOTROP.

\section{References}

Astudillo Espinosa C (1978) Aspectos de la malacología médica en las enfermedades parasitarias. Revista de la Facultad de Ciencias Médicas de la Universidad Central del Ecuador IV: 51-62.

Ausserer A (1871) Beiträge zur Kenntniss der Arachniden-Familie der Territelariae Thorell (Mygalidae Autor). Verhandlungen der Kaiserlich-Königlichen ZoologischBotanischen Gesellschaft in Wien: 117-224.

Bank RA (2017) MolluscaBase: Classification of the recent terrestrial Gastropoda of the World. . Database Available from: https://www.marinespecies.org/aphia.php?p=sourcedetails\&id=278821 (July 5, 2021).

Borrero FJ, Araujo R (2012) Clarification of the taxonomic status of Isomeria morula (Hidalgo 1870), from Ecuador (Gastropoda: Pleurodontidae). Journal of Conchology 41: $145-152$.

Breure ASH (2020) Type material of taxa described by Cousin and Jousseaume in the Royal Belgian Institute of Natural Sciences, Brussels. Folia Malacologica 28: 95-113. https://doi.org/10.12657/folmal.028.005

Breure ASH, Borrero FJ (2008) An annotated checklist of the land snail family Orthalicidae (Gastropoda: Pulmonata: Orthalicoidea) in Ecuador, with notes on the distribution of the mainland species. Zootaxa: 1-40. https://doi.org/10.11646/zootaxa.1768.1.1

Breure ASH, Araujo R (2017) The Neotropical land snails (Mollusca, Gastropoda) collected by the 'Comisión Científica del Pacífico.' PeerJ 5: e3065. https://doi.org/10.7717/peerj.3065

Cisneros-Heredia DF (2017) The type localities of Anolis aequatorialis Werner, 1894 (Sauria: Iguania: Dactyloidae) and Pristimantis appendiculatus (Werner, 1894) (Amphibia: Anura: Craugastoridae). Zootaxa 4216: 190-196. https://doi.org/10.11646/zootaxa.4216.2.5

Correoso Rodríguez M (2008) Los moluscos terrestres y fluviales del Ecuador continental, la biodiversidad desconocida. SIMBIOE, Quito. 
Correoso Rodríguez M (2010) Nuevo reporte y localidades de Rhodea cousini Jousseaume, 1900 (Gastropoda: Subulinidae) para el Ecuador. Revista Geoespacial: 45-51.

Correoso Rodríguez M (2020) Moluscos y arte en Ecuador. Casa de la Cultura Ecuatoriana, Quito, 88 pp.

Cousin A (1887) Faune malacologique de la République de l'Équateur. Bulletin de la Société Zoologique de France: 187-287.

DIPLA Escuelas Régimen Costa, Distrito Metropolitano de Quito.

Dunker G (1882) Molluscis nonnullis terrestribus Americae australis. Jahrbücher der deutschen malakozoologischen Gesellschaft: 377-380.

Fulton HC (1908) Descriptions of two new species of Synapterpes. Journal of Molluscan Studies 8: 84-85.

GAD Pichincha Mapa politico y vial.

Germain L (1907) Sur quelques mollusques de la République de l'Équateur (Mission de M. le Dr. Rivet). Bulletin du Muséum national d'histoire naturelle 1907: 52-68.

Germain L (1911) Étude sur les mollusques terrestres et fluviatiles recueillis par M. le Dr. Rivet. In: Mission du Service Géographique de l'Armée pour la mesure d'un Arc de Méridien Équatorial en Amerique du Sud sous le contróle scientifique de l'Academie des Sciences 1899-1906. Tome 9 Zoologie. Gauthier-Villars, Imprimeur-Libraire du Bureau des Longitudes, de l'Ecole Polytechnique, Paris, C1-C77.

Hidalgo JG (1893a) Capítulo II: Catálogo de las conchas terrestres recogidas por los naturalistas de la comisión científica española en diversos puntos de la América meridional. In: Obras Malacológicas de J. G. Hidalgo, Parte III, Descripción de los moluscos recogidos por la Comisión científica enviada por el Gobierno Español á la América Meridional. Imprenta de Don Luis Aguado, Madrid, 75-134.

Hidalgo JG (1893b) Capítulo Primero: Descripción de especies nuevas. In: Obras Malacológicas de J. G. Hidalgo, Parte III, Descripción de los moluscos recogidos por la Comisión científica enviada por el Gobierno Español á la América Meridional. Imprenta de Don Luis Aguado, Madrid, 33-74.

Hidalgo JG (1893c) Descripción de los moluscos terrestres recogidos durante el viaje al Pacífico, verificado de 1862 a 1865 por una Comisión de naturalistas enviada por el Gobierno español. In: Obras Malacológicas de J. G. Hidalgo, Parte III, Descripción de los moluscos recogidos por la Comisión científica enviada por el Gobierno Español á la América Meridional. Imprenta de Don Luis Aguado, Madrid, 134-331.

ICZN (1999) International Code of Zoological Nomenclature. 4th edition. International Trust for Zoological Nomenclature, London. Available from: https://www.iczn.org/thecode/the-code-online/.

IGM (1990) Carta topográfica: Calacalí CT-EII-E4. 
Jarrín MJ (2021) La red erudita de Paul Rivet en el Ecuador: Agentes, saberes y objetos. Boletín de la Academia Nacional de Historia 99: 145-168.

Jousseaume F (1887) Mollusques nouveaux de la République de l'Équateur. Bulletin de la Société Zoologique de France: 165-186.

MNHN (2000a) Collection: Molluscs (IM) Set of 2 specimens MNHN-IM-2000-4671 Syntype(s) Synapterpes riveti var. bizonalis Germain, 1907. Muséum national d'Histoire naturelle, Paris. Database Available from: http://coldb.mnhn.fr/catalognumber/mnhn/im/2000-4671 (March 2, 2022).

MNHN (2000b) Collection: Molluscs (IM) Specimen MNHN-IM-2000-28158 Holotype Mesembrinus vesperus Jousseaume, 1887. Muséum national d'Histoire naturelle, Paris. Database Available from: http://coldb.mnhn.fr/catalognumber/mnhn/im/2000-28158 (March 2, 2022).

MolluscaBase (2022) MolluscaBase. Zoniferella Pilsbry, 1906. World Register of Marine Species WoRMS. Available from: https://www.marinespecies.org/aphia.php?p=taxdetails\&id=995660 (March 2, 2022).

NHM (2021) Collection specimens - Specimens - 1908.7.6.89 - Synapterpes bicingulatus Fulton, 1908. Natural History Museum, London. Database Available from: https://data.nhm.ac.uk/object/af6e0eda-a0e3-4aa2-96e43a128a9d1595/1646179200000 (March 2, 2022).

Obando E (2020) Zoniferella riveti. iNaturalist Available from: https://www.inaturalist.org/observations/45333530 (March 2, 2022).

Pilsbry HA (1896) Note on Bulimus hanleyi and B. coronatus. The Nautilus X: 46.

Pilsbry HA (1906) XVIII. Achatinidae: Stenogyrinae and Coeliaxinae Manual of conchology structural and systematic. Conchological Department, Academy of Natural Sciences of Philadephia, Philadelphia, PA, 357 pp.

Simon E (1889) Révision des Avicularidae de la République de l'Écuador. Actes de la Société Linnéenne de Bordeaux XLII: 399-404.

Stegenga B (2022) género Zoniferella. iNaturalist Available from: https://www.inaturalist.org/observations/106477992 (March 2, 2022).

Valdivieso R (1898) Informe del Ministerio de Obras Públicas, Agricultura, etc. al Congreso ordinario de 1898. Tipografía de la Escuela de Artes y Oficios, Quito, 233pp.

Valencia RF (2021) Zoniferella vesperus. iNaturalist Available from: https://www.inaturalist.org/observations/84233579 (March 2, 2022).

Wolf T (1892) Carta geográfica del Ecuador. Available from: https://www.davidrumsey.com/luna/servlet/detail/RUMSEY 8 1 4402 350011:Cart a-Geografica-del-Ecuador-por-Dr (April 10, 2020). 
Supplementary file 1. Known localities of Zoniferella vespera (Jousseaume, 1887) and Z. riveti.

\begin{tabular}{|c|c|c|c|c|c|c|c|c|c|c|c|}
\hline $\begin{array}{l}\text { Species } \\
\text { Zoniferella }\end{array}$ & Collector & $\begin{array}{l}\text { Year of } \\
\text { observation }\end{array}$ & $\begin{array}{l}\text { Year of } \\
\text { publication }\end{array}$ & Locality & Province & Country & Latitude & Longitude & $\begin{array}{l}\text { Uncertainty } \\
\text { in km }\end{array}$ & $\begin{array}{l}\text { Elevation } \\
\text { in } \mathrm{m}\end{array}$ & $\begin{array}{l}\text { URL } \\
\text { https://www.inaturalist.org/observat }\end{array}$ \\
\hline $\begin{array}{l}\text { vespera } \\
\text { Zoniferella }\end{array}$ & Patiño & 2018 & 2018 & Mindo, valley of & Pichincha & Ecuador & $-0,082382$ & $-78,732394$ & 0,357 & 1700 & $\begin{array}{l}\text { ons/17046546 } \\
\text { https://www.inaturalist.org/observat }\end{array}$ \\
\hline $\begin{array}{l}\text { vespera } \\
\text { Zoniferella }\end{array}$ & Schön, ML & 2017 & 2022 & $\begin{array}{l}\text { Mindo, valley of } \\
\text { Pachijal, Un Poco de }\end{array}$ & Pichincha & Ecuador & $-0,068408$ & $-78,765328$ & 2,73 & 1300 & $\begin{array}{l}\text { ons/104455797 } \\
\text { https://www.inaturalist.org/observat }\end{array}$ \\
\hline $\begin{array}{l}\text { vespera } \\
\text { Zoniferella }\end{array}$ & $\begin{array}{l}\text { jOrdis } \\
\text { Cianferoni }\end{array}$ & 2020 & 2020 & $\begin{array}{l}\text { Chocó } \\
\text { San Francisco de las }\end{array}$ & Pichincha & Ecuador & 0,052973 & $-78,84228$ & 0,004 & 1170 & ons/66893276 \\
\hline $\begin{array}{l}\text { vespera } \\
\text { Zoniferella }\end{array}$ & $\mathrm{F}$. & 2009 & 2020 & Pampas & Cotopaxi & Ecuador & $-0,41994$ & $-79,00623$ & 1,5 & 2000 & $\begin{array}{l}\text { ons/62317763 } \\
\text { https://www.inaturalist.org/observat }\end{array}$ \\
\hline $\begin{array}{l}\text { vespera } \\
\text { Zoniferella }\end{array}$ & Gelis, R & 2018 & 2018 & Mindo, valley of & Pichincha & Ecuador & $-0,090101$ & $-78,732673$ & 0,244 & 1700 & $\begin{array}{l}\text { ons/17060451 } \\
\text { https://www.inaturalist.org/observat }\end{array}$ \\
\hline $\begin{array}{l}\text { vespera } \\
\text { Zoniferella }\end{array}$ & aguilargm & 2019 & 2020 & Séptimo Paraiso & Pichincha & Ecuador & $-0,030523$ & $-78,766507$ & 0,647 & 1600 & $\begin{array}{l}\text { ons/45556832 } \\
\text { https://www.inaturalist.org/observat }\end{array}$ \\
\hline $\begin{array}{l}\text { vespera } \\
\text { Zoniferella }\end{array}$ & Vizcarra $S$ & 2014 & 2020 & Mashpi Lodge & Pichincha & Ecuador & 0,165901 & $-78,877605$ & 0,212 & 900 & $\begin{array}{l}\text { ons/40932386 } \\
\text { https://www.inaturalist.org/observat }\end{array}$ \\
\hline $\begin{array}{l}\text { vespera } \\
\text { Zoniferella }\end{array}$ & scibugs & 2020 & 2020 & Séptimo Paraiso & Pichincha & Ecuador & $-0,028831$ & $-78,762188$ & 0,263 & 1600 & $\begin{array}{l}\text { ons/37584288 } \\
\text { https://www.inaturalist.org/observat }\end{array}$ \\
\hline $\begin{array}{l}\text { vespera } \\
\text { Zoniferella }\end{array}$ & Grijalva, $S$ & 2019 & 2019 & $\begin{array}{l}\text { Estación Mindo USFQ } \\
\text { Pachijal, Un Poco de }\end{array}$ & Pichincha & Ecuador & $-0,035311$ & $-78,752791$ & 0,05 & 1600 & $\frac{\text { ons } / 21849408}{\text { https://www.inaturalist.org/observat }}$ \\
\hline $\begin{array}{l}\text { vespera } \\
\text { Zoniferella }\end{array}$ & wouter-oe & 2019 & 2019 & Chocó & Pichincha & Ecuador & 0,052339 & $-78,843231$ & ? & 1100 & $\frac{\text { ons } / 20837253}{\text { https://www.inaturalist.org/observat }}$ \\
\hline $\begin{array}{l}\text { vespera } \\
\text { Zoniferella }\end{array}$ & Valencia, $\mathrm{R}$ & 2021 & 2021 & Reserva Otonga & Cotopaxi & Ecuador & $-0,41667$ & $-79,01667$ & 1,65 & 1900 & $\begin{array}{l}\frac{\text { ons/84233579 }}{\text { https://www.inaturalist.org/observat }} \\
\underline{ }\end{array}$ \\
\hline $\begin{array}{l}\text { vespera } \\
\text { Zoniferella }\end{array}$ & Falero, D & 2019 & 2019 & Mindo, valley of & Pichincha & Ecuador & $-0,08223$ & $-78,733098$ & 0,019 & 1700 & $\begin{array}{l}\text { ons/32975401 } \\
\underline{\text { https://www.inaturalist.org/observat }}\end{array}$ \\
\hline $\begin{array}{l}\text { vespera } \\
\text { Zoniferella }\end{array}$ & Gelis, R & 2020 & 2020 & Mindo, valley of & Pichincha & Ecuador & $-0,078526$ & $-78,731235$ & 0,404 & 1600 & $\frac{\text { ons/47932409 }}{\text { https://www.inaturalist.org/observat }}$ \\
\hline Zoniferella & Ramon, $\mathrm{G}$ & 2021 & 2021 & $\begin{array}{l}\text { Mindo, valley of } \\
\text { Los Puentes, type } \\
\text { locality of Zoniferella }\end{array}$ & Pichincha & Ecuador & $-0,048717$ & $-78,775198$ & 2,17 & 1300 & ons/82077716 \\
\hline vespera & Cousin & & 1887 & $\begin{array}{l}\text { vespera } \\
\text { San Tadeo, type }\end{array}$ & Pichincha & Ecuador & 0,045833 & $-78,674167$ & 2 & 1500 & \\
\hline $\begin{array}{l}\text { Zoniferella } \\
\text { riveti }\end{array}$ & Rivet & & 1907 & $\begin{array}{l}\text { locality of Zoniferella } \\
\text { rivet } i\end{array}$ & Pichincha & Ecuador & $-0,0291$ & $-78,7526$ & 2 & 1700 & \\
\hline
\end{tabular}

